\title{
STATE OF FEAR: CONTROLLING THE CRIMINAL CONTAGION IN SUHARTO'S NEW ORDER
}

\author{
Joshua Barker
}

In keeping with the overt symbolism that marked political monuments in Suharto's New Order, the Department of the Interior on Jakarta's main square was ornamented with a giant kentongan. A kentongan is an instrument made from a hollowed branch that is struck to give off a sound. Kentongan have been used by neighborhood watches (ronda) in Java's towns and villages for centuries as devices to keep thieves away, to call forth populations for territorial defense, and to keep people alert and ready to ward off threats to community well-being. ${ }^{1}$ Hung by a mosque, in a guard house, or in front of the village head's house, it is the quintessential technology for community policing. The kentongan at the Department of the Interior, by virtue of its size and location, would seem to represent a departure from the strictly local connotations of village kentongan. This grand kentongan was undoubtedly meant to provide the many thousands of kentongan in the nation's villages and towns with a new center with which to resonate. Through a sort of crude symbolism, the installation of this kentongan signified the subordination of local security apparatuses to the overarching security framework provided by the state.

The buildings that comprise the Department of the Interior are themselves representative of what is a characteristically New Order architectural style: large

${ }^{1}$ On the various functions and meanings of the kentongan and the ronda, see Joshua Barker, "Surveillance and Territoriality in Bandung" in Figures of Criminality in Indonesia, the Philippines, and Colonial Vietnam, ed. Vicente L. Rafael (Ithaca: Cornell Southeast Asia Program, 1999). 
buildings which appear top-heavy since their upper floors, supported by long concrete columns, extend out beyond the lower ones. Such a style-most commonly seen in the thousands of banks that sprang up in all of Indonesia's towns and cities during the boom periods of recent decades-emphasizes two features of the building: the entranceway and the upper floors. The entranceway can be of monumental proportions, with a ceiling several stories high, giving the visitor a distinct feeling of being very small. The upper floors, in contrast, allow their inhabitants to sit atop the structure and survey the scene below, often from behind a wall of one-way glass. On the occasions that I was forced to visit the Department of Interior between 1995 and 1997 (to report my research plans to the Socio-Political affairs bureau), I could not help but notice that the coupling of this architecture of surveillance with the kentongan did not quite work. Although the kentongan was given monumental proportions and carved with intricate designs so as to make it stand out to those who beheld it, it was clearly added after the building was constructed, for it had been pushed off behind a column so as not to get in the way. Without a spot of its own, it simply hung there, looking uneasy and out of place.

This paper will examine the New Order state's attempts to appropriate local, territorial power and to give it a place within the confines of the state. ${ }^{2}$ Specifically, it will focus on the effects of two initiatives pursued by the New Order state to use surveillance to eliminate and discipline representatives of territorial power: Petrus and Siskamling. Petrus is the acronym given to an early-1980s paramilitary operation known as the Mysterious Killings ${ }^{3}$ (Pembunuhan Misterius) in which thousands of people labeled criminals were murdered in a number of Indonesia's main cities. Siskamling, or sistem keamanan lingkungan (environment security system), is a term that was first coined by the head of the Indonesian police in the early-1980s to describe a new way of organizing the local security apparatus so as to give police the responsibility for coordinating and supervising neighborhood ronda, and for training and supervising private security guards (satpam) for use in commercial and public settings. ${ }^{4}$ Both of these initiatives were means of dealing with fears regarding a wave of violent crime that peaked in the early-1980s. At a policy level, the two initiatives moved in two different directions since one implied the eradication of the criminal element through what the government referred to as "shock therapy," while the other

2 In this paper, territorial forms of power are represented by the kentongan, the ronda, the tattoo, and figures like the jawara and preman. For an account of how territorial power is constructed by the ronda and the kentongan, see Joshua Barker, "Surveillance and Territoriality in Bandung."

3 Also meaning Mysterious Shootings (Penembakan Misterius) or Mysterious Shooters (Penembak Misterius).

4 Among the police it is also frequently called the sistem swakarsa. The Police have defined it as: "Unity and sameness of people's understanding, attitude, behavior within various living environments that arise in the shape of care toward preventing, prohibiting, tackling, and responding in an appropriate and speedy way to tendencies and/or cases of disturbance of order, crime, and calamities that could or are striking at their interests, themselves, or their surroundings, along with being able to take care of themselves in accordance with changing circumstances." Pusat Pengembangan Imu dan Teknologi Kepolisian, Laporan Akhir Penelitian Industrial Security dan Permasalahnya (Jakarta, 1994), p. 4. 
implied the development of a better system of law enforcement through an extension of the reach of the Police. According to Bourchier, officials in government were divided as to which strategy to pursue: some advocated the rule-of-law approach represented by Siskamling, others advocated the extra-judicial approach represented by Petrus. ${ }^{5}$ In retrospect, however, it seems clear that the two solutions to the crime problem were effectively part of a single process. This process had as its object the "deterritorialization" 6 of local security practices in a manner that was conducive to central state control. In the case of Siskamling, this was largely an institutional question which depended on subjecting gangs, security guards, and "criminals" to surveillance. But in the case of Petrus, it was a question of appropriating the power that "criminals" and gangs represented, a complex process that involved mimicry as well as surveillance.

This paper is based on a combination of textual sources and field research. ${ }^{7}$ It begins with a brief account of crime, security, and state power in the period immediately leading up to Petrus and the introduction of Siskamling. This is followed by a description of the changes to local security brought about by the implementation of Siskamling, changes that would only really get underway once Petrus had scared competitors away or killed them. The bulk of the paper is then spent analyzing Petrus itself: its lists, its ambivalence in defining the "criminal," and its attempts to recuperate the power that gangs and their leaders represented. Finally, the paper describes the legacy of Petrus and Siskamling for the relation between local security and state power.

\section{Crime, Security, and State Power in the Early-1980s}

The raging crime at the beginning of the 1980 s, especially armed robbery directed at gold shop owners and bank clients, was a hot story in Bandung's media. The news was consumed by the people via the mass media so that it became a specter [momok] that caused the people fear. The criminals' actions were

\footnotetext{
5 David Bourchier, "Crime, Law and State Authority in Indonesia" in State and Civil Society in Indonesia, ed. Arief Budiman (Clayton, Victoria: Monash University, Asia Institute, 1990), p. 183.

${ }^{6}$ For definitions of deterritorialization, see Gilles Deleuze and Felix Guatarri, A Thousand Plateaus. Capitalism and Schizophrenia (Minneapolis: University of Minnesota Press, 1991), especially pp. 61, 141-144, 453-456. My use of the term is somewhat analogous to Weber's use of the term "transpose" as in the following: "Bureaucratic and patriarchal structures are antagonistic in many ways, yet they have in common a most important peculiarity: permanence. In this respect they are both institutions of daily routine , , , The patriarch is the 'natural leader' of daily routine. And in this respect, the bureaucratic structure is only the counter-image of patriarchalism transposed into rationality. As a permanent structure with a system of rational rules, bureaucracy is fashioned to meet calculable and recurrent needs by means of a normal routine." S. N. Eisenstadt, ed., On Charisma and Institution Building (Chicago: University of Chicago Press, 1968), p. 18 (emphasis added).

${ }^{7}$ Fieldnote citations are indented and signaled by the phrase [Fieldnotes] at the beginning of each section. The statements of informants were not recorded verbatim (unless in inverted commas) but were reconstructed shortly afterward from contemporaneous notes. Names of informants have been changed for obvious reasons.
} 
performed not just at night in fact but in broad daylight and in the middle of public crowds. ${ }^{8}$

The criminal specter came out of the shadow into the light of day at a particular time: the early-1980s. ${ }^{9}$ It appeared first in the mass media, then among the crowds, and soon after in Police theses like the one from which the above quotation is taken. There are several ways to explain why criminality appeared as a threat when it did. In the broadest terms, one could point to the fact that, in the history of the New Order, the early-1980s was a watershed period in both economic and political terms. Economically, 1973 to 1981 saw a tremendous oil boom which gave the state unprecedented revenues and leeway in pursuing policies of economic nationalism.10 By 1982, however, the first signs of the oil bust began to appear, leaving the state in a weakened position with respect to foreign capital. As a result, 1982 and 1983 saw the introduction of liberalization policies, significant cuts in subsidies of energy and food, and a 27.6 percent devaluation of the currency. ${ }^{11}$ Politically, the regime was also beginning to show the possibility of fracture. ${ }^{12}$ Student demonstrations against the New Order in the late-1970s were followed in mid-1980 by the Petition of Fifty, in which many former supporters of Suharto expressed their opposition to the regime. Proponents of human rights and legal reform also managed to push through a new Code of Criminal Procedure which-on paper at least-curtailed some of the powers of the Police. In addition, beginning in 1979, a new, more professionally trained generation of military officers started to be appointed to command positions, a development that had the potential to undermine Suharto's monopolistic control over the military. ${ }^{13}$ Finally, enough time had passed since the killings of 1965 that the specter of a re-emergent PKI (Indonesian Communist Party) had begun to lose some of its currency: threats to public order were increasingly portrayed as being "purely criminal" rather than as being manifestations of underground "political" opposition. Against the backdrop of these wider developments, the criminal specter can be seen both as the symptom of a structurally weakened state (and society) and as a convenient excuse for actions aimed at trying to overcome this weakness.

\footnotetext{
8 W. P. Nainggolan, "Penggunaan Lokasi Pertokoan yang Dilaksanakan Oleh satpam dalam Rangka Menunjang Tugas Poltabes Bandung" (BA thesis, Jakarta: Perguruan Tinggi Ilmu Kepolisian, 1984), p. 44.

${ }^{9}$ On the way in which the solar eclipse of 1983 was used to justify the mysterious killings, see John Pemberton, On the Subject of "Java" (Ithaca: Cornell University Press, 1994), pp. 314-316. On the shadowy world of crime during the colonial period, see Henk Schulte Nordholt, "The Jago in the Shadow: Crime and 'Order' in the Colonial State in Java," Review of Indonesian and Malaysian Affairs 25: 1 (Winter 1991): 74-92.

${ }^{10}$ According to Winters, 1981 saw the peak in availability of state discretionary funds. Jeffrey Winters, Power in Motion (Ithaca: Cornell University Press, 1996), p. 122.

11 Richard Robison, Indonesia: The Rise of Captital (Sydney: Allen \& Unwin, 1986), pp. 125, 382-384.

12 For a detailed account of tensions between members of the political elite and how they played themselves out in the Petrus campaign, see the excellent analysis by Bourchier, "Crime, Law and State Authority in Indonesia."

${ }^{13}$ Harold Crouch, The Army and Politics in Indonesia, rev. ed. (Ithaca: Cornell University Press, 1988), p. 357.
} 
When the specter of crime appeared, it took very particular forms: gali-gali and jawara (or jegger, jago, bromocorah, etc.). ${ }^{14}$ The former term, an acronym for "gangs of wild kids" (gabungan anak-anak liar), refers to organized gangs of people involved in criminal behavior, while the latter terms refer to professional criminals or charismatic toughs. ${ }^{15}$ Taken separately, there was nothing new about these fears and their objects. Jawara and their ilk had been a source of fear in Java for many generations, as numerous studies have demonstrated. ${ }^{16}$ Similarly, at least during the New Order, the existence of youth gangs in urban areas had periodically been a matter of concern. ${ }^{17}$ With the rise in violent crime in the beginning of the 1980 s, $^{18}$ however, both jawara and gali-gali came under increasing scrutiny by the press and the government. Attracting particular concern were those jawara and gali-gali that were active in businesses or gangs providing "security services": debt collection, bodyguard rentals, security guard rentals, and the like. Such groups were thought to be taking crime into a new, organized, and supra-local realm. Both Siskamling and Petrus took these organizations as their object of attention.

\section{Siskamling ${ }^{19}$}

Siskamling was started in 1980 as an off-shoot of a larger government program called Kopkamtib (Komando Pemulihan Keamanan dan Ketertiban, or Command for the Restoration of Security and Order). ${ }^{20}$ It represented an attempt by the New Order government to impose overt state control over local security practices by taking them

14 In East Java they were known as bromocorah, in Sundanese as jegger. A jegger is not so different from a jawara, except that the term has more criminal connotations. Bromocorah has closer connotations with black magic.

15 According to Siegel, contemporary newspaper accounts of Petrus portrayed gali-gali as having the following characteristics: they were excessively violent (sadis), they were organized, they took in a lot of money, they had an uncontrolled force of expression, and they desired what everyone else desired. James T. Siegel, A New Criminal Type in Jakarta. Counter-revolution Today (Durham: Duke University Press, 1998). For a description of preman, see Loren Ryter's article in this volume.

16 Onghokham, "The Inscrutable and the Paranoid: An Investigation into the Sources of the Brotodiningrat Affair" in Southeast Asian Transitions: Approaches Through Social History, ed. Ruth T. McVey (New Haven: Yale University Press, 1978), pp. 112-157; John Smail, “Bandung in the Early Revolution, 1945-1946" (PhD dissertation, Cornell University, 1964); Sartono Kartodirdjo, Protest Movements in Rural Java: $A$ Study in Agrarian Unrest in the Nineteenth and Early Twentieth Centuries (London: Oxford University Press, 1973); Schulte Nordholt, "The Jago in the Shadow"; Robert Cribb, Gangsters and Revolutionaries: The Jakarta People's Militia and the Indonesian Revolution 1945-1949 (Honolulu: University of Hawaii Press, 1991).

17 For the most part, however, the Police regarded such gangs as a problem of juvenile deliquency and not as a serious threat.

18 For the statistical characteristics of this crime wave, see Bourchier, "Crime, Law, and State Authority in Indonesia."

19 Parts of this section have appeared in my "Surveillance and Territoriality in Bandung."

20 Kopkamtib was a structure of command initiated in 1965 . Headed first by Suharto, and later by Sumitro and Sudomo, its aim was to "restore national security and order" by establishing a group within the military which had extraordinary powers and did not have to follow laws of criminal procedure. During the 1960s and 1970s, Kopkamtib was primarily used to eliminate, or at least frighten, "communists" and to suppress political dissent. Siskamling and Petrus marked a shift in Kopkamtib away from political threats to "criminal" threats. 
out of the hands of organized private gangs. As the Chief of Police and founder of the program, Awaloedin Djamin, explained in his autobiography:

We definitely did not want to have the same thing happen in Indonesia that happened in other countries. In Japan, for example, the Yakuza forced protection on business people. Such a situation can give rise to excesses that are difficult to overcome. The same was true in the early days of the mafia in the United States. ${ }^{21}$

The Indonesian "security" groups Awaloedin was likely referring to were mainly of two types. The first groups were local, territorial gangs based in residential districts that had, over time, spread to adjacent bus terminals, markets, or shopping centers. In most major cities there were dozens of such gangs and turf wars were common. Many of these gangs were formed in the early days of the New Order and had been active in providing local "defense" in the context of the anti-communist pogroms. ${ }^{22}$ Some derived their authority from charismatic leadership, some from the fact that their members' parents were prominent officials in the government or military, and others from their successes in turf warfare. ${ }^{23}$ By the beginning of the 1980s, some of these local gangs had actually become quite large, and as their members grew older, had become rather professionally-minded in their provision of "protection" to local businesses. ${ }^{24}$ The second set of groups consisted of legal organizations rather than gangs. One of the most prominent of these was Pemuda Pancasila, the nation-wide youth group described elsewhere in this issue. Others included foundations and businesses formed by ex-convicts and others with few job possibilities. These groupslike Prems, Massa 33, and others-provided security services to shops, transport companies, wealthy business people, etc., by hiring out "guards" for the protection of particular locales, individuals, events, or traffic routes. Some of the larger groups, like Massa 33, claimed memberships of as many as fifty thousand people, almost all exconvicts and street-people. ${ }^{25}$

\footnotetext{
21 Awaloedin Djamin, Pengalaman Seorang Perwira Polri (Jakarta: Pustaka Sinar Harapan, 1995), p. 240.

22 In South Jakarta alone in 1970, the Police listed thirty-nine gangs. The names of some women's gangs: The Fu Man Chu, The Single Girl, The Pretty Doll, Monalisa, The Hunter Boys, Amigos. Regional gangs: Banten Boy, Batak Boy, AMS (Ambon-Maluku-Seram). ABRI (Armed Forces of the Republic of Indonesia) gangs: Gang Siliwangi, Gang Beerland, Gang Panser. Mixed gangs: Santana, The Trouble, SBC (Santa Barisan Setan), MBC (Manggarai Boy's Club), Sarlala (Sarang Laba Laba), Kasko (Kami Selalu Kompak), Kobel, Tjablak, Scarlet BCD, Motor Scarlet, Flamboyant, Devil Kids, The Casanova SK 700, Provost, Chabreek, 9 AK, Mr. Lonely Heart, The Bat Boy MDC, The Flaming Gos, Leo Patra, The Legos. In Bandung: Mexis, AMX, BBC (Buah Batu Boy's Club), Melos (Menak Lodaya Sadis), Megas (Menak Galunggung Sadis), Amek (Anak Muda Emong Karapitan), Hippies Dago, Dollar, Patorados, Bexis, TXC. See Soenarjo, "Suatu Analisa Tentang Tumbuhnya Gang Anak-Anak/Pemuda di Djakarta" (BA thesis, PTIK [Perguruan Tinggi Ilmu Kepolisian], 1970), pp. 59-63.

23 For a study of a jawara-based gang, see Ayip Muflich, "Mardy Pelingung Gang (Suatu studi kasus)," (BA thesis, Criminology Department, Universitas Indonesia, 1979).

24 See, for example, the study of Gang "X", a gang which showed strong tendencies toward bureaucratization. See Leonard Tomasoa, "Kepemimpinan dalam Gang X (Suatu Studi terhadap Kehidupan di Gang di Dareah Kebayoran Baru)" (BA thesis, Criminology Department, Universitas Indonesia, 1981).

25 On Massa 33, see Farid Mappalahere, "Organisasi Massa 33 (studi kasus organisasi pengamanan swasta di Surabaya)" (Surabaya: Airlangga University, PLPIIS, 1981/1982); see also Surabaya Post, March 18, 1995. p. 2.
} 
For the Police, the growth of such private security services constituted a serious threat to their authority. Not only "protection" but even the pursuit, capture, and punishment of suspects was increasingly being entrusted to these groups rather than to the Police. Siskamling aimed to counteract this tendency by establishing clear controls over such non-state security businesses; it was hoped that Police control would prevent them from becoming mafia-like protection rackets (or at least that the Police would have a stake in these protection rackets). But Siskamling did not just target security businesses. In the domain of volunteer residential security as well, Siskamling aimed to establish a system for centralized monitoring and control, one of the aims of which was to discourage acts of communal violence against suspected thieves, sorcerers, and adulterers (and, undoubtedly, the Police themselves, as they were often targets of such violence). Moreover, Siskamling had purposes beyond just the monopolization of violence and the recuperation of "police" repressive powers. Both gangs and neighborhood watches were extremely effective tools for day-to-day surveillance of the population, and Siskamling provided a rubric for integrating them into the bureaucratic surveillance machine. In all these respects, then, Siskamling was viewed as a handy concept for increasing Police powers under conditions of an extremely low police to population ratio; and to do so at little or no added cost to the state. ${ }^{26}$

Siskamling's system of control worked by dividing local security guards into three types: satpam (Satuan Pengamanan, or Security Unit), Kamra (or "hansip"), 27 and ronda (night guard). In general, satpam guards were responsible for protecting commercial and public buildings and spaces, while hansip and ronda guards were responsible for patrolling residential neighborhoods. Satpam and hansip were salaried and uniformed guards while the ronda, a far older institution, was still based on community obligation and used no uniforms. All three elements of the security system were brought under the control of the "Guidance of Society" (Bimbingan Masyarakat, or Bimmas) division of the Police. ${ }^{28}$ Because the guards were not paid by the Police, however, Bimmas's sole functions were surveillance and training. This new system, which was centered around the satpam, was explicitly meant to represent a departure from older forms of territorial security like the ronda and the jawara. As the head of Bimmas in Jakarta summed it up:

A satpam has two "heads"; the firm, house or office at which he or she is employed, and the police, from whom he-or she-gets training ...

Being a satpam is a profession. A satpam is not a tukang ronda malam [voluntary neighborhood watch], nor are they centeng [thugs]. They don't just open the door for people...

\footnotetext{
${ }^{26}$ In 1994, the ratios of the number of police agents to population in several countries were as follows: Hong Kong: 1:220; Thailand: 1:228; Malaysia: 1:249; Singapore: 1:295; New Zealand: 1:416; Japan: 1:563; Philippines: 1:665; Indonesia: 1: 1,119. Asia Week, April 20, 1994.

27 While technically called Kamra (Keamanan Rakyat, or Peoples' Defense), these guards are generally referred to as "hansip."

${ }^{28}$ In addition to its work with Siskamling, Bimmas is also involved in training and working with youth groups.
} 
14 Joshua Barker

What satpam basically do is the police's job, that's why we train them and are responsible for them. ${ }^{29}$

The satpam was defined by what he or she was not: a thug, an old-fashioned voluntary ronda, or some kind of servant. Like the Police, he or she should be treated with respect, and should consider himself or herself to be a professional.

In the new system, Bimmas would ensure, in the first place, that all schools, neighborhood organizations, markets, businesses, and so forth had an individual or committee responsible for overseeing "security"; this would facilitate co-ordination between the Police and those who paid the guards' salaries. The Police would also, however, survey the guards themselves. As part of this surveillance, satpam and hansip guards were to be counted and classified according to the education and training they had received. There were to be three-month and one-month courses provided for satpam by the Police. ${ }^{30}$ Such courses would include training in military formation, marching, self-defense, and how to guard a vital industry, combined with some lessons on how to make reports to the police, how to keep track of the identities of those coming and going from offices, factories, or housing complexes, and what procedure to follow when one caught a suspect in a crime. Those who passed the basic training course would be allowed to possess knives; and those who went through a special screening process would be eligible to have guns. While the hansip did not have such a special training course, in principle its members were to join the satpam at the local police station each week for training. Moreover, all three types of guards-the ronda included-were to be "controlled" at their posts on a regular basis by patrolling members of Bimmas. On these more informal occasions, the police could make sure the guards were well-organized, gather information about threats for their intelligence reports, and give advice. Finally, to distinguish them from the public and from other security services, satpam and hansip guards were to wear standardized uniforms and carry identification issued by the Police. The satpam's uniform would consist of black pants and a smart white shirt with logos on the arms and a label on the front saying "satpam"; that of the hansip was comparable but all in an army green.

It was not just the guards themselves who were to be revamped. The security posts that used to be known as gardu or pos ronda were to become "pos kamling." They were now to be counted, inspected, and classified according to their facilities; it was to be noted, for example, what building type the pos had (i.e. from what materials it was constructed), and whether it had weapons, maps, flashlights, beds, and so forth. Based on this information, the Police could then work together with hansip and ronda guards to improve the facilities by making recommendations to the heads of RT's and RW's (Neighborhood Associations) about what had to be purchased (it was they who had to find a way to pay for improvements). Through a process of kentonganisasi, every pos kamling would be obliged to have a kentongan and a standardized code for warning of danger, as well as a list of who was responsible for guarding at what times. Ideally, pos kamling should also have handcuffs, weapons, and a phone, along with maps of the

\footnotetext{
29 Jakarta Post, October 13, 1996. Centeng is translated by the journalist as "thugs" but in pre-Siskamling terminology it meant simply "night-watchman" (of warehouses, etc.).

30 In Bandung in 1996, more than half of the satpam guards working had attended these.
} 
area they patrolled, lists of important residents, lists of so-called residivis, ${ }^{31}$ and rules for the patrols. ${ }^{32}$ These visuals and lists would mimic those found at the local police station. Similarly, the pos keamanan (security post) that was usually to be found in the parking lot or lobby of commercial establishments was to be subject to the same sorts of monitoring and recommendations made to satpam employers if facilities were lacking.

In sum, if the program was a success, every locale-be it a neighborhood, a shop, a mall, a restaurant, a bus terminal, a government building, a parking lot, a schoolwould have at least one designated guard and an individual or committee responsible for working with the Police to supervise and organize both the watch and any other security measures. The guards themselves-through their training and use of Police modes of surveillance-would act as local representatives of Police authority.

The only real problem with this plan as it was introduced in the early-1980s was that people would not choose satpam and hansip over existing commercial security services. Not only did ex-convicts and gangs instill more fear in potential robbers and thieves, but they also instilled more fear in businesses and communities. In its earliest manifestation Siskamling thus tended to work not directly with the buyers of security services but with the sellers: those who controlled the gangs. Agreements were made with many of the emerging businesses run by ex-convicts and others, all of whom undoubtedly liked the idea of being legitimized by the state in return for submitting their members to training and guidance. For a brief period between 1980 and 1981, the Police, local government, and businesses created by gangs and ex-convicts thus enjoyed an openly co-operative arrangement that was probably economically beneficial for all involved. It was probably also politically beneficial to the ruling party, Golkar, which reportedly made use of these groups for strong-arm tactics in the run-up to the 1982 elections. The honeymoon was short-lived, however. In June 1982 the Chief of Police, under the banner of Kopkamtib, put out an order that effectively banned private security businesses. ${ }^{33}$ While it was legal to offer security consultation to businesses, to train prospective security guards, and to sell security devices, it was prohibited to rent out employees as guards. Furthermore, those businesses that continued to operate in the more restricted domain set out for them were subject to increased regulation. One regulation was that employees had to be able to provide a "Letter of Good Behavior," 34 meaning that no ex-convicts would be eligible to work in such firms; another forced firms to receive permission for their businesses from the provincial Police commander, and, if they intended to serve areas outside that command, from the national chief of police.

\footnotetext{
${ }^{31}$ Residivis has a broader sense than the English word recidivist: it refers not just to "repeat-offenders" but often to "ex-convicts" as well.

32 Much of this mirrors the type of intelligence apparatus set up in East Timor. Compare, for example, the account found in Richard Tanter, "The Totalitarian Ambition: Intelligence Organisations in the Indonesian State" in State and Civil Society in Indonesia, ed. Arief Budiman (Clayton, Victoria: Monash University, Asia Institute, 1990), pp. 244-245.

33 Surat Keputusan Kapolri No. Pol. SKEP/220/VI/1982. June 14, 1982.

34 The police-issued "Letter of Good Behavior" is a required document for almost any employment outside the informal sector (with the exception of foundations and businesses set-up for employing and
} 
As a result of this new policy, many of the newly-established private security firms shut down or were driven underground. Prems Surabaya, for example, which in February 1982 had met with members of the provincial congress (DPRD, Dewan Perwikilan Rakyat Daerah) and optimistically claimed that it anticipated a membership of fifty thousand people, about 60 percent of whom would be ex-convicts, officially broke up less than a month later. ${ }^{35}$ Prems Jakarta, on the other hand, restricted its official activities to providing legal aid and job-training to ex-convicts, while nonetheless continuing to offer illegal debt-collection services and security services. ${ }^{36}$ In Bandung, where the first official security guards were known as Satpamsus (Satuan Pengamanan Khusus), the new policy had the effect of reducing the powers of the camat (head of the kecamatan, or sub-district). Initially, Satpamsus had been under the control of the camat and the heads of RT/RW, with some oversight from the Police and the Army. Under that system, the camat and RT/RW officials had been the ones profiting from commercial security, since they collected money from shops and factories in their areas and hired out local toughs to keep security. With the new regulations, however, the camat and RT/RW were restricted to involvement in residential security, while control over commercial security became the responsibility of an alliance between business owners and the Police.

Perhaps the most interesting case, however, was Massa 33, which had been started in the early-1970s by a gang of calo 37 but had grown to be one of the largest of the exconvict organizations, with branches throughout East Java. It continued to operate illegally for a time, but was eventually the target of a Police operation. As a result of this operation (and with permission from the Army and Surabaya's mayor) the Police, working together with the head of the bus terminal, took down personal data on everyone, supposedly screened-out the hardened criminals, and arranged for some of the others to undergo training to become satpam. At Surabaya's bus terminal, where Massa 33 had been started, these reformed gang members were then mixed in with an equal number of non-Massa 33 satpam and all became employees of the terminal. ${ }^{38}$ In other words, Massa 33's organization was destroyed, but its reformable elements were integrated into a new organization based on the co-operation between the Police and the terminal head. To ensure that the gang did not survive as a force within this new organization, it was diluted with non-gang members. Furthermore, since the remaining members of the gang were considered to be employees of the terminal rather than members of an outside organization, they could be subjected to all sorts of governmental and firm-based controls.

In sum, the overall result of the government's policy was to deny gangs and private security firms their economic and legal bases, and to appropriate, and subject

reforming ex-convicts). This regulation thus closed off one of the few avenues ex-convicts had to regain the rights of ordinary citizens, condemning them to a life of economic-as well as social-exile.

35 Surabaya Post, February 22, 1982, p. 2; Surabaya Post, March 8, 1982, p. 2.

36 Teuku Ashikin Husein, "Jasa-Jasa Keamanan oleh Yayasan Prems di Wilayah Pertokoan Blok M" (BA thesis, PTIK, 1983).

${ }^{37}$ Calo is a term meaning agent, broker or go-between. Calos at bus terminals approach customers to sell tickets and then demand a cut from bus drivers or bus companies.

38 One of the reasons ABRI was in favor of satpam was that it would provide an employment opportunity for low ranking retirees whose pensions were very small (and perhaps would keep them out of trouble). 
to Police surveillance, their "reformable" elements. This policy-in combination with the "systematization" and regulation of existing ronda practices-set the stage for a massive expansion of Siskamling into all domains of urban life, a process that would continue throughout the 1980 s and 1990 s. $^{39}$ It also created a situation in which gangs that continued to operate were criminalized (with notable exceptions like Pemuda Pancasila), while those which disbanded were divided into clear groups of corrigibles and incorrigibles. In other words, it set the stage for Petrus.

\section{Petrus}

According to David Bourchier, who has analyzed the way the Petrus campaign unfolded, the killings of "criminals" began in earnest in March 1983 in the Central Javanese city of Yogyakarta and lasted for at least two years. ${ }^{40}$ During that time at least five thousand and perhaps more than ten thousand people deemed bromocorah, preman, or gali were killed. The killings were concentrated in the larger cities, like Jakarta, Surabaya, Bandung, Medan, and Semarang. Although the killings were condemned by international human rights groups, many press accounts were more or less approving of the government's methods for much of the campaign. While there were critics who complained that such extra-judicial punishments would undermine the rule of law, press interviews with people "on the street" almost invariably indicated a certain relief that "criminals" were being eliminated from city bus terminals, train stations, markets, and squares. (These sentiments seemed to have changed little fifteen years after the bulk of the killings took place).

\section{Surveillance or Death: Lists, Operations, Tattoos}

From the standpoint of its organization, Petrus was rooted in the tradition of surveillance. It depended first of all on a process of identification, which provided a representation of the "criminal" element in society, and secondly on an operasi that targeted particular people in the world "out there" based on the labels that had been attached to them. It was planned and organized centrally (most likely) by General Benny Murdani who then had control over the Armed Forces, Kopkamtib, and military intelligence; and it employed a discourse borrowed from hygiene operations, claiming

39 The non-gang guards that were hired were initially mostly low-level ABRI retirees, but as the program expanded the guards came to include young men and women, almost all of whom were either villagers or people who came from the poorer areas of towns.

40 Bourchier, "Crime, Law and State Authority in Indonesia," p. 185. In September 1982, before Petrus began, the family of a military commander in East Java had been murdered by thugs. The military's response to this was to avenge the killings by executing the suspects and throwing their corpses in a river. Nico Schulte-Nordholt, "Violence and the Anarchy of the New Order State" (unpublished). It is likely that this event and similar killings in the Jember-Bondowoso area some months before were the immediate models for the Petrus killings. See Bourchier, ibid, p. 185. One wonders, however, if these East Java commanders got their idea from a wave of killings they had handled in Jember in 1981. The victims of these killings, of which there were twenty-seven, were accused of being sorcerers and bromocorah, and were killed by the "masses" from villages where they lived. They too were tied-up or placed in sacks and thrown into rivers. Surabaya Post, March 2, 1981. 
to be aimed at "cleansing" the nation's cities of the criminal "cancer" that threatened them. ${ }^{41}$ Bourchier describes the way the killings took place as follows:

Criminals, gang members, or ex-prisoners, frequently tattooed and almost always young and male, would be met in their houses or in the street by a group of four or five heavily built men. In many cases they would shoot their victim where they found him. More often the would bundle him (or them) into a jeep or Toyota Hardtop and drive off into the night. The victim would be taken to a quiet place and shot through the head and chest at close range with .45 or .38 caliber pistols. His corpse would then either be tossed into a river or left in some public place outside a cinema, a school or on a footpath of a busy street. Victims frequently had their hands bound, and often bore marks of torture. The following day there would be a short report about the finding of a "mayat bertato," (tattooed corpse) in the local paper, usually accompanied by grisly pictures. 42

Bourchier goes on to note that there were also a number of mass graves to which large numbers of people were brought, killed, and their bodies dumped. This was done on a highly routinized basis: on every Friday and Sunday, for example. In the early part of the campaign, people living near the graves were permitted to witness these killings.

From this description of the killings, it is clear that they followed a pattern very similar to less violent operations which were such a prominent feature of New Order life: operations against becak, drugs, prostitution, vagrants, women's fertility (i.e. Family Planning), and the like. Just as in the operasi aimed at drugs, for example, the agents descended on their targets and removed them from the scene in order to maintain an image of order. The removal was then followed by the staging of a spectacle in which the targeted objects or people were shown to have truly been eliminated (the dead bodies displayed for all to see and the drugs crushed or burned). ${ }^{43}$ Furthermore, as with operasi like those conducted under the rubric of Family Planning, the solution Petrus posed for the criminal contagion was not just elimination but heightened surveillance. Bourchier's description of the mechanics of Petrus in Yogyakarta highlights these two objectives:

The procedure in Yogyakarta appears to have been that police intelligence supplied the garrison commander (Komandan Kodim) with a list naming hundreds of suspected criminals and ex-prisoners in the region. The garrison then put together a black list and issued a public ultimatum to all galis (without, however, naming names) to "surrender immediately" to the garrison headquarters. Those who did, and these numbered several hundred, were required to fill out detailed forms, providing their life history as well as data on all their family members and friends. They were also required to sign statements agreeing to refrain from criminal activities or face "firm action" from the authorities. Each gali was obliged to carry a special card and report to the

\footnotetext{
41 Bourchier, "Crime, Law and State Authority in Indonesia," p. 184.

42 Ibid, p. 186.

43 Pemberton, describing the killings in Solo, notes that the Solonese morgue during this period, which was inundated with corpses, had a kind of open-door policy for people to come and look. Pemberton, On the Subject of "Java," p. 312. For a description of the logic of more mundane operasi, see my "Territoriality and Surveillance in Bandung."
} 
garrison on a regular basis. Those who did not turn up to be registered, or did not keep their appointments with the garrison, were hunted down and killed by squads of military men.4

In making its ultimatum to the public, the garrison was saying that it already had completed the process of identification and had a list of "criminals" in its possession. How were these criminals identified? Bourchier notes that the source of this list was the Police. The existence of such lists was, in fact, nothing new, since police and village heads have been compiling lists of so-called "butterflies," bromocorah, and residivis in their regions since the early part of the century. ${ }^{45} \mathrm{With}$ the Petrus ultimatum, however, these lists took on a new significance. In the past, residivis subjected to heightened surveillance were clearly listed by local authorities and the rules of reporting laid out. There was no mystery about such lists and there was actually a fair amount of flexibility about who was listed since a person who behaved well in his community might well be left off the lists because of a local official's "oversight." Moreover, the lists themselves served a primarily administrative function, with the work of actual surveillance being carried out by the ronda and spies. This meant that a "butterfly" was kept aware of his status as a suspect by being subjected to repetitive monitoring by his peers. The Petrus ultimatum changed this state of affairs in three ways. In the first place, it said that the lists had already been compiled and so there would be no flexibility in the process of identification. Second, it made a point of keeping the contents of the lists secret. Third, it proposed an unprecedented equation: an unsurveilled "criminal" was equivalent to being dead. Each of these points will be discussed below.

In Indonesia, the idea that a government decision cannot be changed is usually greeted by cynicism accompanied by statements to the effect that in Indonesia anything is possible with money and influence. Indeed, one of the more common mantras recited by everyone from coolies to elite lawyers is that: "In Indonesia, everything can be bought." Yet when speaking of blacklists such an attitude is far less prevalent; even people who are otherwise unimpressed by state power show a certain anxiety and respect when the topic comes up. Consider, for example, Mr. Yanto, an older man living in Bandung who fitted very closely the definition of a Petrus target. As a youth he had been a member of street gangs, become known as a fighter, and later joined a group of armed robbers. Just after Petrus he completed a seventeen-year prison term for murder and armed robbery, and when I met him he was working as a bodyguard for an ethnic Chinese businessman. He was a gruff man and prone to sudden outbursts of anger, but he was also past middle-age, a bit weary, and not as good at hiding his kindness as he undoubtedly had been at one time. Nonetheless, he was always extremely self-confident and felt capable of manipulating all sorts of outcomes in his relations with the police, judges, and others. When I raised the topic of Petrus, it was he who mentioned the lists and became visibly frightened by the possibility that he might be on a post-Petrus blacklist. When I suggested that he might be able to pull some strings to make sure his name did not appear on such a list, he

\footnotetext{
44 Bourchier, "Crime, Law and State Authority," pp. 185-186.

45 For a description of list-taking practices at the start of the century, see my "The Tattoo and the Fingerprint: Crime and Security in an Indonesian City" (PhD dissertation, Cornell University, 1999), chapter 3.
} 
responded that it was impossible: “Once your name is on that list, it's done. You can't do anything about it."

That blacklists might be taken to be immutable-and could actually be so in many cases-shows that they are close to the heart of the state's power. At stake for the state in such lists is something far greater than the fate of the individual in question and greater even than the benefits derived from establishing interpersonal debts. It is something important enough that to subtract a name from the list would constitute a threat to state power of the first order. ${ }^{46}$ A clue as to what this might be is provided by a story not about the Petrus blacklists but about their political counterpart. It was told to me by a wealthy businessman in the private sector. As a person with some influence, he had gathered together some high-level military men in hopes of getting political charges against an old friend from his hometown dropped. Accustomed to dealing with such figures in the context of his business, he thought he might at least be able to make sure that his friend was charged with something more minor. But in the meeting, when he explained that his friend did not pose a threat and that his offending actions had been a mistake, they asked him: "Do you know who [your friend] really is?" They then proceeded to ask him questions about his friend's daily activities, which he could not answer. Finally, they refused to do anything in the case, saying, "Even if you've known [kenal] him for a long time, you can't be certain you really know [tahu] who he is." It was an event that clearly made a lasting impression on the man, since he told the story to me more than once; moreover, the way he told it made it clear that the questions had genuinely caused him to doubt whether he knew his friend or not.

The story shows that what was at stake for the state in its blacklisting was nothing less than its power of recognition. The state needed to privilege its own "truth" about peoples' identities over competing claims about who people really are. By making the lists immutable, state representatives establish a domain where the authority of local knowledge, familiarity, and the like are ultimately denied, and where the knowledge produced using state surveillance techniques is stated to be "true." In the years before Petrus, it might have been possible to use one's own perception of oneself or one's neighbors' perceptions of one to influence the way one was identified by the state. Certainly, it was possible to maintain a local identity that did not directly correspond to that on the files in the state archive. In this respect, many "criminals" were actually regarded as heroes in their local communities. With the Petrus ultimatum, however, any other sources of recognition were denied. In the end, the ultimatum asserted, the state knows people better than their friends do; better even than they know themselves. And although all sorts of other "truths" dictated by the government may be subject to localization and corruption, this domain is untouchable.

The Petrus lists were not only immutable, they were also secret. This was important because not only because it asserted the exclusivity of state knowledge but because it demanded that all citizens ask themselves if they might be "criminals." In principle, at least, the situation was not so different from that during the killings of "communists" in 1965 and 1966 when people were forced to ask, "Am I PKI or nonPKI?"; only now they were forced to ask themselves about their "criminality."47 To

\footnotetext{
46 Adding names, because of local and personal politics, was probably more acceptable.

47 See the famous article by Pipit Rochijat, "Am I PKI or non-PKI?" in Indonesia 40 (October 1985): 37-56.
} 
answer this question they had to imagine what the state perceived criminality to be and how the state imagined them to be. And since the contents of the lists were not made public, the implicit demand was that anyone who had ever been remotely suspected by the state, had been in prison, or had committed a crime, should voluntarily recognize himself as suspect, even if the person immediately judged himself to be innocent in this regard. ${ }^{48}$

Failing to recognize oneself as the state did could prove fatal: if one's name was on the list and one did not submit to heightened surveillance, one could be killed. ${ }^{49}$ It was those people who hid from the state, or even worse, asserted another identity against that given to them by the state who would be killed. Lieutenant Colonel Hasbi, the Acehnese head of Yogyakarta's garrison, put this in the starkest terms when explaining why the shootings were necessary: "Why shoot? Basically we want to work in a humane way. But there are those who want to fight back. They want to show off their self-identity [identitas dirinya]." 50 It was these types, those who refused to submit to registration and monitoring, choosing instead to "show off" their own identities, that the campaign targeted. The state was thus reserving the ultimate power of recognition for its surveillance apparatus: the power over life and death. In theory, at least, agreeing to suspect one's own criminality, not just one's politics, was the new condition of survival for subjects of the New Order state.

That Petrus identified its "criminal" victims through blacklists and that the campaign was designed to demonstrate the overwhelming power of surveillance is only one side of the story. The other side is more interesting and difficult to understand, and it concerns a quite different impression that developed in many quarters regarding how victims were identified. In brief, it was the impression that targets for the killings were identified not by hidden lists but by the very visible markings on their bodies: tattoos. Certainly many ex-convicts had tattoos, but rumors seemed to suggest that having tattoos was sufficient in itself for identifying a criminal, and that the mysterious shooters were hunting down anyone with tattoos. Such rumors might well have originated in press reports about the discovery of corpses which frequently made reference to the victims' tattoos. In any case, the rumors were taken seriously enough that many people with tattoos were sufficiently frightened that they tried to get rid of their tattoos. During a period of just two weeks in June 1983, two hospitals in Bandung recorded sixty-three people who paid to have plastic surgery to remove tattoos. Others tried to remove their tattoos themselves. Many inmates at Bandung's prison cut their skin off with razor blades or tried to burn their tattoos off using caustic soda; others outside the prison used hot irons (nowadays, one frequently sees bus conductors and the like with huge scars where their tattoos used to be). ${ }^{51}$

\footnotetext{
48 In Yogyakarta, the people Tempo mentioned as being worried about this ultimatum are all members of protection rackets and gangs (i.e. calo, petugas keamanan). Tempo, April 16, 1983, p. 54.

49 Of course there was no guarantee that those who reported to the authorities would not themselves be killed (for a case of this in Yogyakarta, see Tempo, April 16, 1983, p. 54). And we will never know how many people failed to report because they were too frightened of being killed and how many failed to report because they did not see themselves as suspect and thus were not frightened at all.

50 Tempo, May 14, 1983, p. 55.

51 Surabaya Post, June 18, 1983, p. 1.
} 
How are we to understand this alternate explanation for how Petrus targets were identified? What is the relation between visible tattoos and hidden lists? The relation between lists and tattoos as methods for identifying "criminals" and targets for killings could be understood to be an unproblematic supplemental relation. This is, at least, the gist of the following remarks, which were made toward the end of the Petrus campaign in 1983 by a member of Reserse's (Criminal Investigation Division of the Police) Identification section in Jakarta:

It is clear that a tattooed person is not [necessarily] a criminal, but as I often handle the various types of criminals there are, there has at last arisen an indirect impression when I see a tattooed person, such that my inner voice says, "Why it's just like a criminal." And the majority of those who often wear tattoos are those who really are criminals, which is to say, those who have been in and out of prison or who have been blacklisted by the police. And in connection with my work, it is clear that tattoos are special signs that have to be noted in people's identity files, particularly those who have business with the police. And as a matter of fact, historically, before the discovery of a fingerprinting system, tattoos were used as a means for identification just like brands made with hot iron. ${ }^{52}$

This police officer, at the nation's center of criminal identification and registration, conveys his belief that tattoos are an "indirect" sign of criminal identity. Someone like him, he suggests, who has had countless occasions to look back and forth between the lists of convicts and the bodies before him, can pretty safely say that there is a correspondence between "criminals" defined by technologies of surveillance and bodies with tattoos. In this initial comment, we see one possible way in which tattoos might have functioned as a support of the state's claims that its lists and its operations were very precise. For as soon as doubts about precision emerged, people could be reassured by the indirect evidence that the bodies that were turning up in rivers and on the streets were not just any bodies, they were tattooed bodies. For him the reassurance came not just through experience but also through a chain of associations that allowed him to get from criminals to tattoos via identity cards and back to criminals again via fingerprints. This chain of associations went as follows:

criminal_prisoner_blacklist_identity file_tattoo noted in file_tattoo on body_brand on body_fingerprint_criminal.

This chain of associations ensures that the gap between the bodies in the world "out there" and the identities on file is bridged by an intermediate figure: the fingerprint or the tattoo. Yet two things about the policeman's statements suggest that he is giving tattoos more significance than the files would. First, he notes at the end of the chain of associations that brands and tattoos historically preceded identity files (fingerprints, lists, etc.) as a way of signifying the "criminal," thereby giving the latter a primacy over the former. Second, he says that whenever he sees tattoos his inner voice (hati) says, "Why it's just like a criminal." These statements work against what he started off saying, which was that tattoos signify criminality only by virtue of a

52 Cited in Arief Sumarwoto, "Latar Belakang Kebiasaan Pelaku Kejahatan Tertentu Memakai Tatto Sebagai Salah Satu Ciri Penampilannya" (BA thesis, PTIK, 1984), p. 77. This thesis itself raises the question of whether a person wearing a tattoo is necessarily a criminal. It indicates that the association between the two-and their life or death implications-did not always sit well with the police. 
statistical correlation. Rather, it turns out that they are "special signs" that in him provoke an immediate equation with criminality even when they appear on someone not being processed for heightened surveillance. If this is the case, might it not then be possible that the lists used in Petrus had a similar re-enforcing effect on what had been a prior suspicion of tattoos? Consider the statements of a food seller at a market in Jakarta:

It's clear that people with tattoos are criminals [penjahat] Pak, or at least that their hearts and actions aren't good. Before, almost every night the small traders here were asked for money. It's true it wasn't a lot, Pak, but that money meant a lot to us. After a time I came to know the person, but didn't know him really well. He turned up only asking for money and then left again. He and his friends indeed had tattoos as their distinguishing marks. So that this gave rise to a hunch that tattooed people are criminals. What's more when meeting those guys, at least I had to be careful, maybe they could be criminals [jangan-jangan orang ini penjahat]. My hunch was strengthened after I read in the papers that lots of tattooed people were shot to death, and they said all of them were criminals. But now we here are all calm because those guys who asked for money each night are no longer. Maybe they ran away or were shot by someone. ${ }^{53}$

Here one finds what is probably the most ubiquitous local description of a preman or jegger: someone who is known, but to whom one would not admit being close, who wears tattoos, and who turns up asking for money. With respect to the tattoos, this man's answer shows a movement from (at most) a hunch to something near certainty that the tattoos he sees mean criminality (and therefore someone whose death is meaningless). One can see in the "jangan-jangan orang ini penjahat" that the recognition of whether this person really is criminal, rather than just being "not good," is something that has to come from outside (or perhaps, that if it came from inside the local sphere the man would already have been killed). The confirmation of his suspicion comes from the reports he reads about Petrus.

In sum, while the explicit targets of the Petrus campaign were professional and violent criminals, the way in which these criminals were identified was subject to two interpretations. One interpretation suggested that identification primarily followed the logic of surveillance. In this interpretation, tattoos were merely a supplemental form of identification (found on corpses) that could have the effect of containing fears about who criminals were. You could see with your own eyes that not just anyone was being killed. Another interpretation suggests that the targets of Petrus were not ex-convicts and repeat offenders as defined by law and by the surveillance apparatus, but people with "special signs" on their bodies. In this interpretation tattoos were already cause for suspicion about someone's "criminality" and the state's lists and dead criminals acted to confirm what-in retrospect at least-one already knew. The fact that tattoowearers might be the real targets of Petrus caused Arief Sumarwoto, the policeman who wrote the thesis from which the above quotes were taken, some consternation. In his thesis he interviews convicts, police, and others, and does statistical analyses to determine what percentage of so-called residivis wear tattoos and what percentage of tattoo-wearers are residivis. Writing during Petrus, he was clearly bothered by the fact

53 Ibid., p. 75. 
that targeting tattooed bodies might lead to operations like Petrus killing the wrong people. Perhaps he was disturbed by the operation and had to write about its injustices even if they were defined merely as a technical failure of reference; or perhaps he had a tattoo himself.

By suggesting that blacklists were not the only way "criminals" were identified at the time of Petrus, I am not trying to argue that Petrus in fact targeted tattoo-wearers rather than repeat-offenders. Although it is entirely possible that the above thesiswriter's fears (fear shared, as we have seen, by tattoo-wearers) were justified, and that people were killed simply for having tattoos, the centralized, bureaucratic form Petrus took makes it likely that lists were what actually determined who was killed in most instances. Having said this, the centrality given to tattoos as a supposed form of identification during the campaign should not be dismissed. While it may not tell us the names of who was killed, it provides an important clue as to what people believed the campaign was targeting and what the symbolic importance of the campaign was. The final two sections of this essay will address these symbolic questions, first, by way of a rather extended digression on the different meanings that were attached to tattoos at the time of Petrus; and second, by interpreting a few stories told about Petrus and Petrus-like killings by participants and observers of the campaign.

\section{Tattoos and Identity}

In their descriptions of what led them to wear tattoos in the first place, some of Sumarwoto's tattoo-wearing respondents provide a clue as to how these bodily inscriptions relate to identity, and why, for some, they may suggest that someone is anti-social or even criminal.

When I first became a sailor, sailing many seas, months in others' countries, there arose a feeling of longing for my parents, relatives, and friends ... so I tried to look for something to do just for the fun of it. I noticed among my friends those who wore tattoos. I was interested and made some just for fun. And it's true that it can chase away the feeling of loneliness. To fill empty time it was better than just daydreaming, thinking about impossibilities [yang tidak tidak]. ${ }^{54}$

Tattoos, in this context, provide a distraction from desires that cannot be realized by focusing one's attention on what is present, thereby filling the emptiness. They give shape to a self that is based on a disavowal or a postponement of desires for others (family, friends). ${ }^{55}$ This explanation of tattoos was expressed by several of Sumarwoto's respondents, many of whom linked the power of distraction to the pain that making the tattoos caused. For the mariner above, tattoos also became the basis for a collective memory, shared among those who were on the ship; after the passage

\footnotetext{
54 Ibid., p. 68.

55 This is not to say that the self is necessarily an "individual" person; it can be a collectivity too, as in the following: "I first started wearing tattoos because that is what my friends did. Even though our group didn't have a specific name, between us we had customs that we all followed. Because my friends all wore tattoos, I too joined them in wearing tattoos." Ibid., p. 70. Here the group shares its desires but in a way that does not involve taking on a name. It is not a group that is "looking for a name" (as people often say about gangs in Indonesia) by challenging others to duels and by displaying its power.
} 
above he went on to describe how they exchanged tattoos as "mementos" (kenangkenangan) so that when they got home they would not forget their times together. ${ }^{56}$

That tattoos are a way of defining a personal or collective self by localizing desires and by creating a memory of these desires means that they have an affinity to language. In the following statement from a prison inmate, this affinity is exemplified by the fact that tattoos can actually become symbols of what one desires.

The first time I came into the prison in 1979 I saw that many of the inmates had tattoos with all sorts of different pictures. I was attracted and made some myself with the help of some friends who knew how to do it. After I got out of prison the first time I realized that these tattoos were not liked by my parents and they immediately treated me as a child without value. Because of that I felt there was no use anymore in doing good and I made more tattoos on this body of mine. To get money I committed more crimes. Finally I often came in and out of this prison. With all these tattoos I wanted to be valued by my friends. Although my body is small as you can see, in other peoples' eyes I want to be seen as terrifying [serem]. I made these tattoos while I was fantasizing [berangan-angan], fantasizing about things that couldn't be had at the time. Like the picture of the bottle shows that I am a drinker, and the picture of the syringe shows I am a drug addict; and you can see all the other tattoos on my arms, legs, chest, and back that can't even be counted anymore [they are so many]. Me and my friends in the prison already feel that with tattoos on our bodies we are treated as people who are in and out of prison. I feel like I've already been stamped as a criminal. ${ }^{57}$

Here tattoos do not merely localize desire by preventing it from straying beyond the attainable; they actually provide a symbolic representation of what these desires are. (For this man, the desires are so many they cannot even be counted.) While there is undoubtedly some satisfaction in this for the inmate, he also learns that his tattoos make him a bit of a pariah in the eyes of his family. They treat him as a "child without value," and, it seems, refuse to give him money, thereby forcing him to find money by committing more crimes. A good child, presumably, would channel his desire through the family and by virtue of this would be repaid by being given money (the parents' way of indicating their desire). But the tattoos connote a channeling of desires that either stop with his body and its addictions or else lead back to other tattoos worn by inmates and gangs. Either way, the language of tattoos is an alien language that is anathemetic to the language of kinship, 58 and not just kinship but sometimes religion too. The head of the Council of Ulama said this to Sumarwoto:

Allah already created the human body with perfection. If making tattoos is done by causing the body pain, by wounding it and then inserting ink in the scars, then such an action is already wrong, and even more so if this is done without a meaningful aim. These things are reminiscent of the time before people

\footnotetext{
56 In a more Nietzschean vein, one of the inmate respondents claimed that his tattoo was both a memento of having been in prison and a reminder (peringatan) for him to do good so as not end up in prison for a second time. Ibid., p. 68.

57 Ibid., p. 62.

58 This is obviously not the case when the tattoos are a rite of passage for members of kin groups; but then the tattoos are given by the kin community not self-inflicted or gang inflicted.
} 
knew religion. They made tattoos as a tool of worship, or as a reason for bodily invulnerability, bodily beauty, and so on ... And I hear that people who have tattoos can't be made wet by water. So this will disturb the flow of wudlu water [water of ritual purification] or can cause the failure of the obligatory bath. It's clear that all of this cannot be brought to prayer. ${ }^{59}$

One presumes that a meaningful aim of bodily harm would include ritualized circumcision, which takes place at the hands and under the gaze of selected members of the familial, religious, and neighborhood community. But tattoos do not have such meaningfulness, since they are done "just for fun"; or even if they do have significance, it is a pre-religious, primitive, idolatrous meaningfulness, of which one should be suspicious. As was true in the case of the son and his family described above, desires are channeled in the wrong way; in this case the head of the Council of Ulama asserts that the desires of a tattooed man are channeled to escapism and fetishes instead of to prayer and to God.

In sum, there is indeed a sense in which tattoos assert a certain "self-identity." Both family authorities and religious authorities can find them to be signs of a lack of attention to their respective hierarchies and therefore signs of a misplaced channeling of desires. Undoubtedly the assertion of identity through tattoos is all the more powerful for being territorial: impressed on the body in a permanent form. Especially when they are visible, tattoos serve as a constant reminder to those who see them of an improper channeling of desires.

For the state, tattoos were additionally offensive because they seemed to assert an identity that could not be traced back to state systems of identification. They were precisely not fingerprints or brands, both of which would be stamped using the hands of the Police under the watchful eye of the state. Tattoos, rather, were self-inflicted, and in prisons at least, were done in hiding from the guards since such practices were against regulations.

With Petrus, however, all this changed. By virtue of the lists of criminals, the corpses displayed for all to see, and the hundreds of newspaper headlines emblazoned with the term "tattooed corpse," tattoos were now both criminalized and indelibly associated in people's minds with a form of death that clearly led back to the state. They had become brands, or as the inmates called them: stamps (cap). The people who found themselves unexpectedly recognized by the eye of eyes had either to accept the omnipotence of that eye by submitting to perpetual surveillance or to risk death. Some tried a different tactic: to rid themselves of this stamp. The scars they created in the process are perhaps the most vivid reminders of what battles over identities entail when they are fought on the surfaces of bodies. And although these scars necessarily point back to Petrus they do so in a way that does not lead back to death but to survival; they indicate someone who was confronted by the state (at least in their thoughts) and lived to have their scars tell the story.

${ }^{59}$ Ibid., p. 74. 


\section{The Power of Tattoos}

While tattoos may assert "self-identity" against kinship, religion, and the state, this only scratches the surface of their apparent power. Tattoos are often associated with something far greater, like invulnerability. In this regard, they make greatest sense when inscribed on the bodies of jawara, or jago, who are known for their courage and fighting skills. Their ability to "horrify," in the words of the inmate respondent above, fits well with what the jago and jawara stand for. In the responses given to Sumarwoto, this power of tattoos to cause fear is a constant theme. Some indeed craved this power. Another inmate:

My attitude has always been that I want to be considered a jagoan, so not long after entering into prison I often stood out in various activities, and in tattoos too I made as many as possible. With so many tattoos on my body many people pay attention to me.60

Here tattoos are part of a larger "attitude of acting like a game cock" (jagoan). They make him stand out by making people pay attention to him. Not all people wanted this extra attention. One of the respondents actually feared that he would be recognized as someone too powerful: "I felt scared [coming into prison with so many tattoos] that I would be stamped as the most jagoan."61 Those who did want the power tattoos provided them, however, got many and put them in the most visible places. Magically, these were not merely seen as attributes of the jago character, however, but as powers in their own right. Another inmate:

Those inmates who truly [betul-betul] are not bad/criminal [penjahat] usually they only wear a few tattoos and these are in hidden locations. It's like after having tattoos there arises a feeling of pride so that it gives off an impression of being admired [dikagumi], respected [disegani], and all this gives a push to increase one's daring to be determined no matter what [keberanian untuk berbuat nekad]. 62

Having visible tattoos, by giving an impression of being admired, actually pushes one to be nekad or determined. It is as if they have a force of their own that creates a determination with no bounds. An "unlimited power of expression," as Siegel called it. This force comes from the ability of tattoos to capture others' attention, to implicate their desires in one's own. The appropriation of such power begins with a process of mimicry:

It felt good to have tattoo capital on the body [modal tatoo di badan], there was a feeling of being respected, especially by those who just entered the prison. I remember the first time I entered prison, if I saw someone with lots of tattoos, in my gut I felt fearful too, and even more so if his body was big. After I got out of prison for the second time, the capital I had from having been in prison, along

60 lbid., p. 65.

61 Ibid., p. 66. This respondent also noted that he did not put the tattoos on all at once because there was no way he would have been able to stand the pain.

62 Ibid., p. 66. 
with the large number of tattoos on this body of mine, added to my confidence to do crimes. ${ }^{63}$

Seeing himself (and others) fearing and paying attention to tattoos, this inmate wants this attention for himself. He mimics them so that he too will have the power he desires: the fear and respect of new inmates. The power that he gets from this mimicry is a form of capital that gives him the courage to commit more crimes which makes more people admire him, which makes him commit more crimes, etc. It is difficult to see where this process would end (except, perhaps, in Petrus).

With this man, it is not just that he "desires what everyone desires" (money, a nice house, etc.), as Siegel has noted, ${ }^{64}$ but that he desires what some people do not desire: other people's attention. His command over other people's attention, by virtue of his fetishized tattoos, is what makes him such a fearsome character and makes them respect him. Everyone is looking at him. And insofar as they share his desires too, he has charisma. At least he does for as long as inmates are "new" and he can still command their attention.

When the specter of crime appeared in the light of day in the early-1980s, its effect was not unlike the effect tattoos had on new inmates. Or at least that is how the media and the government portrayed it. The gali-gali seemed nekad in their audacious crimes, and through the press everybody was looking at them, admiring and fearing their power. Their organization of protection rackets, moreover, seemed to give their power currency which they could trade for economic gain. It was as if a hierarchy based on tattoos, duels, and territorial authority was taking shape alongside established hierarchies based on kinship, office, and rank. This was not merely a question of "selfidentity" but a question of political power. Of course, it is difficult to imagine that these organizations posed any genuine threat to President Suharto's authority. Most of the organizations were more like unions of the disenfranchised than mafias. Furthermore, even those organizations that had not been formed under the auspices of the military were quickly subordinated, through Siskamling, to Police and government authority. So why did President Suharto opt for Petrus? It may have been, as Bourchier has suggested, that such organizations were tied into a particular fraternity ${ }^{65}$ within the military and that Suharto felt threatened by this alternative power base; or that their ties to local authorities threatened to undermine Jakarta's ability to control the regions. ${ }^{66}$ Whatever the immediate political reasons were, we shall see below that Petrus did indeed have consequences both for the power of fraternities and for that of local communities. In different ways, both were implicated in, and transformed by, the

63 Ibid., p. 63.

64 See Footnote 15 above.

65 My terminology, not his. I use the term "fraternities" to describe such intra-institutional gangs partly because they are overwhelming male and partly because-especially within ABRI-they often trace their alliances (and rivalries) back to the Academy.

66 Bourchier, "Crime, Law, and State Authority in Indonesia," p. 195 
killings whose overall symbolic effect was to appropriate the power represented by "criminals" and embed it within the hierarchy of the state.

\section{Mimicry and Appropriation in the Killings}

\section{1. "Criminals" and the State}

The tendency of killings during the Petrus campaign to mimic the violence attributed to the figure of the gali has been analyzed by James Siegel. According to Siegel, this mimicry is especially apparent in the excessive violence (what the Indonesian press calls sadis, or sadistic) used to kill the campaign's victims. This use of sadistic violence was particularly odd since the express objective of the campaign was to rid society once and for all of such excesses. If that was the objective, why did they use the methods that they supposedly deplored?

[B]y multiply wounding these gali and accusing the gali of acting in just that way, the government, and President Suharto himself, implicitly identified themselves with their victims even as they asserted their differences from them. It is the imitation of the criminal that is predominant while the assertion of difference at this point was mere camouflage.

... . The government . . . turned gali into corpses intended to indicate not merely the danger of anyone daring to act as they were presumed to act, but also the unlimited power, inherent not merely in the sadistic quality of these criminals but in something beyond it that made it necessary to kill each criminal several times. When it is unrestricted, the power of the government is claimed to be equal to the power of its adversaries. The force of the government was made equivalent to the power attributed to these corpses precisely when the victims were murdered multiple times. ${ }^{67}$

Exactly how this works on a local level is apparent in the following summary of what happened during Petrus in a neighborhood in Bandung. It was told to me by a young man who was familiar with street culture in that neighborhood.

[Fieldnotes] ${ }^{68}$ In this area alone there were three killed [during the Petrus campaign]. Everyone knows who the preman are because they have their own lokasi [place] from which they collect money. If they aren't paid they will stab people, burn the store, etc. They will often ask people for their watches. People are scared of them and do what they say. To find the preman the military used lists of ex-cons (residivis). The usual way of picking them up was with a Landrover. If kids saw a green Landrover with yellow on the door enter the neighborhood they would run in fear. The military would then go to the preman's house and haul him out into the car (he repeats Landrover as it clearly stood out in his mind). It didn't matter if the preman had already stopped doing bad things, lived with his family, prayed or whatever. He would still be hauled off. One was

\footnotetext{
${ }^{67}$ Siegel, A New Criminal Type in Jakarta, pp. 108-109.
}

${ }^{68}$ Interpolations written down contemporary with the fieldnotes are in parentheses. Those that have been added since by the author are bracketed. 
even a kepala [head of an] RT. When they started turning up dead people talked about how they were being killed. Some of them were shot but wouldn't die because they had ilmu [magical powers]. If they were shot the bullets would enter and they wouldn't be able to get up, but they wouldn't die. The only way to kill them was to tie their feet with benang plastik [plastic string] and to tie their neck with benang plastik, and then to pull (or tie one end to a tree) so that they were held off the ground. It was said that if they touched the ground they wouldn't be able to be killed. Kind of like electric wires which must be suspended in mid-air. The corpses were then always put in a rice sack and dropped in the river or at the outskirts of the city.

This local perspective on Petrus shows the sense of powerlessness in the face of agents of death that come from without. We must assume that when he says "everyone knows who the preman are," he is referring to local knowledge, for when he then describes the victims that were chosen, it turns out that they might have been good and respected members of the community (praying, family, etc.). The lists of the center are portrayed as having an inevitable referentiality about them that the local sphere can do nothing about.

As soon as this misgiving is out of the way, however, the story turns to how these powerful figures were killed. Here, as in other stories we shall see later, the killers are said to believe they are confronting someone who is invulnerable. "If they were shot the bullets would enter and they wouldn't be able to get up, but they wouldn't die." The victims do not die an ordinary death. Rather, their death is one that comes from outside the local sphere and achieves its ends by finding the weaknesses in magical invulnerability. (In this story, the weak point in a man's invulnerability is that he loses his invulnerability when he is lifted out of his territory). Had it been the case that the victims simply died ordinary deaths, this fact alone might conceivably become grounds for questioning the very existence of their powers of invulnerability and charisma. But what the story shows is that in fact the people being killed were invulnerable in relation to ordinary death; it is just that the type of death they experienced was supernatural. The killers had confronted the magical power of their victims with a magic of their own.

It is the continued existence of the supernatural power that makes the story worth repeating, for an ordinary death would be of little or no interest so long after the fact. But as Siegel has shown in an analysis of stories surrounding the discovery of Petrus corpses, the logic of such stories-and therefore, perhaps, the "reason" for making the killings themselves into public spectacles-was such that it shifted the focus of interest from the preman back to the state. ${ }^{69}$ Rather than being fascinated by the criminal specter, people became fascinated with the power of the killers; rather than tracing the source of power back to gangs and other forms of hierarchy, people traced this power back to the state. At least this was the case for as long as the corpses of "criminals," like the tattoos we saw above, had the effect of powerful signs.

${ }^{69} \mathrm{lbid} ., \mathrm{pp} .120-124$. 


\section{Territorial Communities and the State}

Besides identifying itself with the power attributed to the criminal specter, the state also used Petrus to identify itself with the power of territorial communities (or the massa, as it were). This somewhat more explicit identification was based on the supposed similarity between the Petrus killings and cases of main hakim sendiri (taking justice into one's own hands) that preceded Petrus and continued both during and after the campaign. ${ }^{70}$ In cases of main hakim sendiri, members of a community beat and often kill either outsiders caught in a criminal act, such as theft or robbery, or people from the community who are thought to have done something wrong, like having sex out of marriage, committing sorcery, or just being bad characters (i.e. bromocorah, jegger, gali, etc.). In many of these cases, the violence also knows no limits, the targets are the same as those that were victimized by Petrus, and sometimes the body is even disposed of in a manner analogous to how Petrus disposed of many of its victims. Certainly cases of main hakim sendiri are reported in a very similar way to how Petrus cases were reported. Consider, for example, the following case which occurred during Petrus and was reported under the title (in Indonesian): "Recidivist with 'Sweet Memory' Tattoo Killed after being Mobbed by Inhabitants of Kampung Krendang."

The brain of a criminal gang in the area of Kampung Krendang named Miming (25 yrs), just released from Cipinang prison, was killed as he was discovered to be about to commit a crime in the same area last Saturday. The suspect, whose body was full of tattoos, was sprawled out bathed in blood in front of Gang Janda in East Krendang. ${ }^{71}$

Main hakim sendiri cases are subject to the sometimes loose notion of catching people in the act of committing a crime. Petrus, on the other hand, targeted people at any time in any place. Nonetheless, the similarity with Petrus in the reporting of such cases is unmistakable. Indeed, Tempo's article on Lieutenant Colonel Hasbi who explained who Petrus in Yogykarta was targeting was placed on the same page as a discussion of all the recent cases where kampung in Central Java had punished "criminals" to death. The reasons analysts gave for these cases were: "the culture of violence among the people," "letting emotion speak rather than rationality," and "an excess of solidarity." 72 It was an identification that did not escape critics of the government's policy. Adnan Buyung Nasution, who was then head of the Legal Aid Institute, rhetorically asked: "If the people act to main hakim sendiri it's considered anarchy, but if it is the security forces that do it?"73

While the story about Petrus in Bandung throws doubt on how far this identification was successful, there was a sense in which Petrus could be interpreted as the government acting on the behalf of territorial communities, disregarding the law as

\footnotetext{
70 Regarding highly publicized cases before Petrus and the possibility that Petrus mimicked these cases, see footnote 40. For cases after Petrus see, for example, "Two Corpses in a Sack Turn Out to be Recidivists Killed by Villagers," Media Indonesia, September 20, 1996; "Accused of Stealing Piggy Bank, Village 'Jegger' Dead by Mass Punishment," Suara Karya, December 15, 1995; "Preman Thrown in River," Suara Karya, August 20, 1996.

${ }^{71}$ Harian Berita Buana, July 25, 1983, p. 7.

72 Tempo, May 14, 1983, p. 55.

73 Tempo, May 21, 1983, p. 12.
} 
they did, and establishing an "excess of solidarity" with the people. At the same time, for its symbolic effect the state's violence depended on being distinguishable from that of main hakim sendiri in its territorial sense. Otherwise, one might really have anarchy since the violence would appear as a contagion with no clear source and the state would not be representing the violence but merely participating in it. This could explain why the state, in many cases, found it necessary to claim authorship for the killings and why the killings were conducted in a manner that left no doubt as to who was behind them.

Insofar as the killings did involve an identification with communal violence, they would be comparable to Siskamling's process of kentonganisasi, which as we have seen, was meant to bring all the local territories into one giant security system that derived its meaning from its supposed source in the state. However, with Petrus, it would be not just the community's solidarity that was identified with the state but its violence and its power.

\section{The Locus within the State: Fraternities and Individuals}

Within the state itself, the degree to which the power associated with such killings achieved currency, and the tendency to trace the source of that power upward through the hierarchy to some higher authority or power, varied. The story below was told by Prasetyo, a mid-ranking police officer in Bandung. ${ }^{74}$ Prasetyo himself was probably the most ambitious, and also the most successful, young officer I met in Bandung's police. In contrast to the jaded Reserse agents at the precinct, for example, he was radiant in his appearance and gave the impression that he was someone who worked hard and did things by the book. It was thus quite disturbing to hear him tell this story in a tone of youthful exuberance and pride. It concerns a killing not in the Petrus campaign itself, but one of the many that have followed in its wake. ${ }^{75}$

[Fieldnotes] Prasetyo and I sat on the couch in the division head's office and the two of them discussed who I should talk to from the division for my research on ilmu. Suddenly Prasetyo remembered a story about a case he had had during one of his former postings. When he first started telling the story he was directing it to me, but as he went on he increasingly looked expectantly for responses only from his boss. The story was about a man who was being held in a lockup by the police for having committed some crime (he didn't say what). He was known to the locals as an orang pintar [a person with special powers] and indeed it turned out that he was able to use an ilmu so that he not only talked the police into letting him out of his cell, but even to giving him a gun and letting him go. When the police realized (sadar) what had happened they called for help in finding him. This is how Prasetyo got involved, as he was part of the team that was sent to

\footnotetext{
74 Because of the nature of Petrus, it is difficult to obtain first-hand accounts of what those who conducted the killings thought about it. For the most part, the police I asked denied any knowledge about the campaign or made it clear that it was not something that should be discussed. Nonetheless, I was told some stories about similar events.

75 The impression I was given was that Petrus-like killings have become a standard Police tool for fighting violent crime.
} 
search for the man. The police who had let him escape told Prasetyo to be careful of his ilmu and also said that this man was famous for his huge penis. They caught him at the home of one of his many wives. And it was true, his alat [tool] was bigger than anything that could be imagined (showing with his hands) ... Almost as an afterthought but conveying a sense that this is what really made the story important (not the magic), Prasetyo then looked knowingly at his boss and said in a soft voice (so I wouldn't hear) something that sounded like, "It was a 486." His boss didn't catch it and asked, "What?" "486. We got an order."76 As he said this Prasetyo made a cutting motion at his throat. "Had to be separated (dipisahkan)," he said, still speaking softly.

In this story, the potency of the victim is described in overtly phallic terms. Not only does he have a huge penis, but he can control language, disarm a policeman, and he is the center around which women circulate. An order is received for the man to be killed but the killing "has to" be done in a particular way, namely, the man must be beheaded. It is common lore in Indonesia that someone with magical powers will not actually die unless his head is detached from his body and the two buried separately.77 In Prasetyo's story, this beheading seems to take on the significance of a castration. It is as if the state, for fear of its own loss of potency, is responding not just by killing the victim but by emasculating his power.

That Prasetyo took part in this castration could well have been a source of personal pride quite apart from the recognition that he received from his superiors. But the way Prasetyo told the story suggested that he himself did not lay claim to some superior phallic power. His task was not a personal accomplishment but something that "had to" be done because that is what the orders were. Insofar as the killing was a feat of superior potency, it represented the state's potency, not his. This is not to say that the killing did not serve a purpose for him. One could see that he felt a certain pride, but this pride was the result of having been entrusted with such an important mission. It was as if telling the story was a kind of showing-off about his successes, not in terms of the killing itself, but in terms of the recognition it implied he enjoyed from his superiors. This showing-off was not for my benefit at all but solely for that of his boss, whom he kept looking to for approval as he told the story. This culminated in his use of the coded term (" $\left.486^{\prime \prime}\right)$ for an order to kill, which had the purpose of acting both as a euphemism and as a way to establish a solidarity with his boss by highlighting a "secret" that they shared (and from which I was excluded). In this regard, the story seemed to be part of the currency of "secrets" that helps to constitute fraternal hierarchies in institutions like the Army and Police. Interestingly, his boss did not give Prasetyo the reward of recognition he sought; rather, he chose not to look directly at Prasetyo and to "not understand" what he meant by the code. My impression was that this failure to recognize the killing as deserving of recognition was not caused by a feeling that Prasetyo had committed an indiscretion in front of a foreign visitor, but was actually Prasetyo's boss's way of quietly refusing to use that particular form of behavior as any measure of success. Without explicitly opposing such killings, he was nonetheless implying that his anak buah was not going to improve his status through

\footnotetext{
${ }^{76}$ I could not be sure I had caught the actual code number, but I think it was 486 .

77 I use the masculine pronoun here exclusively because virtually all subjects of police discipline in such cases are male.
} 
"accomplishments" in those terms. Other officers, of course, might be far more responsive to Prasetyo's desire for recognition; and it is easy to imagine how such killings, by virtue of being clandestine and risky ventures, could become an important currency in fraternal alliances.

The second story we shall recount also concerns post-Petrus killings but was told by Joni, a person quite different from Prasetyo. Joni was from military intelligence, rather than from the Police, and moonlighted as a debt collector specializing in collections from ABRI (The Armed Forces of the Republic of Indonesia, Angkatan Bersenjata Republik Indonesia) debtors. Talking to Joni, one had the impression that the quotidian aspects of life had receded entirely from his awareness. He looked at everyone as if they were strangers, even his wife and kid. He lived in fear and in an unsettling but not overt way he imparted fear to those he met.

[Fieldnotes] Joni is the son of an Indonesian Brigadier General and a Dutch woman. His elder brother is a Major heading up East Surabaya's military police. Joni was born in 1968. When he was young his father used to insist that he arrive home right on time. If he was even a few minutes late he had to do pushups. His father was said to have some powerful ilmu as his mother told of how when he was fighting against the Dutch he could run across water. When his father died some years ago his teacher in ilmu started taking care of Joni. Joni and the rest of his family are from Surabaya but the teacher was from Banten. Now his mother lives in Bandung.

Joni went to Akabri [Academy of the Armed Forces of Indonesia, Akademi Angkatan Bersenjata Republik Indonesia] and from there went to East Timor. At Akabri they were given really tough training, like making their way through ditches filled with shit. He graduated from Akabri in 1987 and probably soon after went to Timor, later returning for a second tour of duty. In Timor he held the komando (i.e. was commander) of a battalion that wore long hair and tore its signs of identification from its uniforms because the Timorese would kill them if they knew what unit they were from. He twice led battalions into ambushes, with most of the men being killed. In one of these cases the Timorese were waiting up in trees at night and shot them with bows and arrows. Some got it through the head, some through the throat. Joni then told his men to be quiet and not to move. They waited until they could see where the attackers were and then shot them out of the trees with their AK's. Joni got the leader of these men who was the kepala suku [tribal chief] and cut off his head. He still has a photo of himself holding the man's head. He says that the Timorese have powerful ilmu and that they can even shoot through bullet-proof helmets. Joni was given a tiny Al Quran by his father's guru. Because he has a Dutch mother he never really believed in it. But he brought it to Timor anyway. There were others who said that when he slept they could see two tigers watching over him. He never saw them but once he pretended to be asleep and he could smell them.

When he returned to Surabaya he was given a komando and he and his underlings did some tough things like swimming to Madura from East Java. This is an area known for sharks so he was pretty worried. Having returned from Timor he says he knew nothing about ampun [mercy], feeling like he was still back in Timor (which he attributed to "trauma"). Thus, for example, one night he 
was walking along and a man came up behind him and held a knife to his throat saying that if he moved he would kill him. He wanted money. But he didn't make Joni put his hands up so Joni was able to grab his gun. He then held the gun to the man's head and told him that if he moved he would be shot. Joni then tortured him, beating him and then shooting his kneecap. He always had extra bullets so he could refill his gun, pretending none had been fired.

While in Surabaya he also got at least one special order to kill a dangerous criminal. One of these was a man of whom the police were afraid because he was kebal [invulnerable] to being shot. Joni's order was to shoot him and put him in a rice bag (dikarungin). The man had tattoos all over. When he did it Joni still had long hair and a beard because he had just come back from Timor. He was wearing a long grey jacket. His relatives had told him to make sure to say a prayer before shooting so that the bullet would go through (menembus). Before going he made sure to mengisi [fill] the bullet by saying the ayatkorsi [a prayer to exorcise spirits]. The man was in a market when Joni ran up and shot him in the head saying "wismillah...". And the bullet went through. Everyone around ran away and he put the mayat [corpse] in a bag and dumped it.

He is glad not to be in Surabaya now because during the trial of that case the family of the dead man said, "Oh, this is the man who killed my brother. No matter where he goes in the world we will find him and kill him, and if not us then our children will do it." And indeed a younger brother did appear once and stabbed him in the stomach, and Joni then pulled out his gun and shot him. If he hadn't had been helped by some bystanders right away he probably would have died. (He lifts his shirt and shows the scar). [...]

Recently Joni got an order here in Bandung to kill a penjahat kelas kakap [bigfish criminal] named Rudi. Supposedly Rudi has robbed a bank in Bogor and got away with it, and has raped. He is now in Bandung. The other people in Joni's team are all bapak-bapak [older men] who are in their forties, so they don't want to do it. They passed it on to Joni. Joni is not sure he wants to do it though because he now has a wife and kid. It's been a week since the order came down and he hasn't done anything yet but he probably will have to soon. He is worried that there will be a balas dendam [revenge] and his family will get it. This happened to his elder brother after he had killed a criminal. They came and killed his family, chopping off his wife's legs. Now his brother is known for his toughness. Every criminal who is caught in the area he controls leaves with his legs broken or maimed.

Even more than Prasetyo's account, Joni's stories emphasize the incredible power of his adversaries, be they independence fighters in East Timor or preman in Surabaya. Attributed to all of them is a magical power that makes doing battle with them an almost supernatural affair. In this case, however, Joni is quite clearly using the power of his adversaries to demonstrate his own power: the ilmu passed down from his father that allows him to sleep safely in East Timor and to kill someone in Surabaya who had, until then, been considered invulnerable. Unlike Prasetyo, the authority to which he lays claim has nothing to do with the recognition he receives from his superior 
officers. ${ }^{78}$ (In fact, he was ambivalent about the military hierarchy since he had been court-martialled for striking a superior and thus had lost prospects for much advancement). It has to do, rather, with his survival and killing skills, and the ilmu he inherited from his father. It is especially the latter-his use of a dukun (shaman), his being guarded by tigers, his "filling" of the bullet, and his reciting of the ayatkorsi-that gives him power over death. It is also this that distinguishes him from others in the state (his comrades in East Timor or the Police in Surabaya) who do not have such power.

In sum, the appropriated phallic or magical power of preman is not always given an undifferentiated locus in the "government" or the "state". Rather, individuals and fraternities within the state, through their actions and stories, may seek to control the circulation of this power for themselves.

\section{The Threat of Revenge}

Joni's story also shows, however, that there is an inherent danger in the mimicry of "criminals," for it can lead to a cycle of revenge. The phenomenon of revenge, in which "criminals," kin groups, or territorial communities seek to recuperate the power they lose when the state-or persons or fraternities within it-kill, beat, or imprison people, is a common one in post-Petrus Indonesia. It is evident, for example, in the numerous cases in which communities reassert their own power to main hakim sendiri against the power of the Police in cases of sorcery, theft, sex outside of marriage, and extortion. In cases such as these the Police usually do not risk charging suspects for fear that they themselves will become objects of the community's wrath. When the Police do overstep this line, the usual response is not actual killing but the spectacular destruction of Police precincts by crowds of upset people. The most explosive of these cases occur when the Police are said to main hakim sendiri against someone who is respected locally. ${ }^{79}$ However, even in these cases, it is extremely rare that the communities will actually revenge the crime directly and proportionally, and so genuinely reassert their power over death. Rather, they will restrict their violence to property so as not to challenge state authority directly. Nonetheless their actions are a

78 As Joni talked about his orders, I got the sense that he did not really know where exactly they came from, only that he must obey them. And at no time during out discussions did he mention any of the ideological reasons behind the war in East Timor or the operations against preman. For him the "reasons" for these wars never even entered the picture; he was concerned merely with the power and danger associated with his own role in them.

79 This might trigger full-scale riots, as happened in Tasikmalaya in 1996. In that case, according to one of the rumors circulating right after it occurred, a police commander had sent his son to a pesantren (Islamic boarding school) for disciplining as he had been caught stealing. At the pesantrèn he was caught stealing again and received punishment from the pesantren head. The boy was angry and reported to his father that he had been tortured. Upon hearing this the commander sent some his anak buah to bring in those who were said to have done the beating and revenged the beating by beating them (some rumors said to death). Word of this got out to pesantrèn students and in the riot that ensued almost all the Police stations in the city, as well as shops, churches, etc. were burned and destroyed.

Other interpretations of the same event suggested that the riot was in fact instigated so as to make it look like the people were angry with the Police. These analyses claim that a faction in the Army was the inciter, implying that the real source of such violence is fraternities rather than the masses. 
powerful reminder to representatives of the state that there are other sources of power that count.

In other cases, the revenge against the government is more direct but remains in the realm of fantasy. As one man in Bandung's prison who claimed to be doing time for fraud explained:

[Fieldnotes] All you have to do is a bit of arithmetic. In the time of the PKI, how many people were killed? A million? Now, if all those people had children, how many people is that? Two million? Remember, all those kids grew up without their parents and cannot get jobs because they are stamped PKI. Now add the hundred thousand [sic] people killed during Petrus. All their kids grew up without their fathers and they know who it was who killed them. They ask: why don't I have a father? And they blame the government. That's why the government here is so scared. They know that there are so many millions of people who want to seek revenge.

The man who expressed this fantasy of revenge was an unusual character. He could perform magic to make money disappear and told fascinating stories about his criminal history that stretched the limits of credibility without ever breaking them. Among other things, he claimed to have been a counterfeiter, a dukun, and a fraud artist. But one thing about him was clear: when he spoke, people listened. Whereas the prison's canteen was usually filled with multiple conversations, when he was there everyone else fell silent. And when he spoke about the inevitability of revenge, one almost started to believe it. The revenge he had in mind was not the personal or local forms feared by Joni and local police precincts, however. It was collective, implicating not just preman but all those who had been criminalized by the New Order's repressive regime.

In sum, the process of mimicry that was evident among inmates who desired the power associated with tattoos was also evident in Petrus and its aftermath. As Siegel has shown, the overall function of this mimicry was to identify the state with the power that criminality represented: magical power, the power of unlimited expression, excessive violence. Through this identification, Petrus insured that anyone who took an interest in such power would come to associate it with the state. We have also suggested that "criminality" might not have been the only figure that was being mimicked; the actions of the state could also have been identified with-or perhaps even modeled upon-the most potent moment in the expression of collective territorial power: main hakim sendiri. With regards to the consequences of these forms of mimicry we have made two observations. First, the power that is appropriated to the state may itself be subject to claims by individuals, or function as a currency within fraternities, so that it is not always the state as such that becomes the new locus for this power. Second, both "criminals" and territorial communities, through their threats and fantasies of revenge, offer reminders that they are still forces to be reckoned with. While we will not investigate the implications of these possibilities here, it is important to keep them in mind. 
38 Joshua Barker

\section{Tattoos And Preman After Deterritorialization}

When the power attributed to tattoos and preman is appropriated by the state, it creates a whole new type of preman and even a new type of tattoo. Consider the following newspaper story:

The Malang court last Tuesday sentenced S ( $29 \mathrm{yrs})$ to seven months in prison for having committed fraud by claiming to be a commander of Pomal [Navy Military Police] working as a petrus (mysterious murderer) and extorting [money] from a person who sells games ... Evidence included a TNI-AL [Navy] membership card, a Kodam 0802 [Army] membership card, and a number of threatening letters and lists of names of people who were going to be petrus-ed ...

On Friday October 28 [the victim] was visited by S, an unknown man who claimed to be the commander of Pomal and working as an agent of Petrus. $S$ showed him a list of names who he was going to Petrus, among them two of the victim's younger brothers.

Because he was worried and afraid, the victim did what $\mathrm{S}$ asked and gave him Rp.17,000. On Tuesday November 1 the victim received a letter from $S$ the contents of which demanded Rp.35,000 in order to have the names of his two younger brothers erased from the list of people who were going to be petrus-ed.

[After that the victim reported it to the police who arrested S] ${ }^{80}$

In this story an extortionist claims power for intimidation not by showing tattoos but by showing lists and identity cards. He mimics Petrus mimicking "criminals" like himself. The difference, of course, is that the identity cards and lists this man has derive their power not from a territorial inscription but from state language and its power over death. This language has a source in the state and a claim to referentiality. The importance of this fact became apparent in the man's trial, when the judges asked him about the Army identity card and he told them he found it on the street. Knowing that there was no such thing as a Kodam with a four-digit number "0802" in the world "out there," and therefore that the man's identity cards were counterfeit and his claims false, the judges were able to laugh, secure in their own possession of the truth. 81

Not all such identity cards and lists are so easily dismissed, however. Certainly in the mid-1990s, in the press and on the streets one was always hearing about surat sakti (magically powerful letters) that would clear a business project through any bureaucratic office, people who were kebal hukum (invulnerable to law), and those criminals who were not white-collar criminals but rather preman berdasi (former street preman impersonating civil servants). Ordinary people, moreover, were always going out of their way to show anyone who was interested their own special signs, which, without exception, traced their power back either to an institution like the military or to a fraternity. Stickers on cars that said Kopassus (the Special Forces) or Pom (Military Police), name cards from important officials, identity cards and paraphernalia from the Harley Davidson club (which was known to be headed by a General and fraternity

80 Surabaya Post, January 25, 1984, p. 5.

81 Other cases of these Petrus impostors: "Wanita Pemeras yang Mengaku Penembak Misterius Ditangkap" Surabaya Post, January 14, 1984, p. 3. "Memeras dengan Dalih 'Petrus',"Surabaya Post, June 2, 1984. 
leader) were all examples of the new type of tattoos. They could all be used to intimidate villagers, avoid fines and exactions if one was stopped by the traffic police, and simply to impress one's friends. Periodically the institutions would try and exert their control over the circulation in order to distinguish the "originals" from the "false" ones; for example, by conducting operations to remove ABRI stickers from cars driven by people who could not produce an ABRI membership card. But while the circulation of these special signs or tokens might extend beyond the particular groups of people who could legitimately hold them, this was ultimately a minor point. The important thing was that they derived their invulnerability and magical power from their connection to the state's institutions and fraternities rather than their connection to some other source of power (like territorial gangs, illegal political parties, outlawed religious sects, etc.). In this respect, Petrus might be called a watershed moment as it marked the point at which territorial power became deterritorialized from the figure of the jawara and reterritorialized within the state and its fraternities. That is, it marked the point at which the power that at one time would have been associated with tattoos became subject to a whole new set of disciplines that were rooted in surveillance and fraternities rather than in bodies and localities.

\section{Local Security and the State After Petrus and Siskamling}

Taken together, Petrus and Siskamling changed the face of local security. On a strictly institutional and demographic level, this change was evident in the explosion of satpam and hansip. With preman killed or intimidated, businesses, bus terminals, markets, malls, and so on all came to hire satpam; and many neighborhoods hired hansip. By the end of 1995, there were about 200,000 satpam across Indonesia, making them more numerous than the Police. ${ }^{82}$ That every satpam and hansip had a particular overseer among the Police, and that the Police co-ordinated with the guards themselves, not just their bosses, meant that this expansion of satpam provided a relatively powerful means for disciplining local security practices. ${ }^{83}$ In this respect, Siskamling provided for the extension of Police surveillance into the local sphere. Much of the time, this additional surveillance also acted as the premise for a far greater involvement of the Police in local protection rackets than had previously been possible when such rackets were either under the control of gangs, heads of RT/RW, or the Army. ${ }^{84}$ While there is always a tendency for the type of petty criminals that Petrus targeted to return, the Police deal with this by launching operations much like the ones that preceded Petrus. In these operations, everyone on the streets is rounded up and fingerprinted, some are charged, some are "developed" by the Police, and some are

\footnotetext{
82 Media Indonesia, December 27, 1995. This was approximately one satpam per nine hundred people, while the ratio of police to inhabitants was one officer per 1,200 inhabitants. In urban areas the ratio was far greater. According to Police data, in 1996 in Bandung, there was about one satpam or hansip for every two hundred inhabitants and only one police officer per 733 inhabitants. The total number of satpam in 1996 was 6,345, up from 336 in 1984 and none before 1980.

83 At the same time, Bimmas provided a rubric for expanded Police oversight not just of security guards but of youth groups, pesantren, ojek (motorcycle taxis) drivers, and "informal" local leaders. Many of these received training and coordination from the Police and became what the Police referred to as their "extended arms" (perpanjangan tangan).

${ }^{84}$ Some gangs continued to operate with bekking (backing) from fraternities in the Army or the Police.
} 
sent off to pesantrèn (Islamic boarding schools) or foundations for reform. ${ }^{85}$ In this way the Police maintain their local domination (except in relation to gangs with bekking ${ }^{86}$ from the Army) despite their extremely low numbers. None of this would have been possible without Petrus.

Petrus, however, was about far more than just demographic and institutional changes; it was about the deterritorialization of the power associated with "criminals," jago, and territorial communities, and its reterritorialization within the state. Such deterritorialization proceeded by means of mimicry coupled with surveillance. Mimicry allowed the state to identify itself with the said power, releasing it from its locus in "criminals," jago, and territorial communities. Surveillance, through its ultimatum forcing "criminals" to recognize themselves as the state would or die, and through its control over what "true" identities are, insured that the circulation of this power would lead back to one source: the state. The process was the same as that used for kentonganisasi: a copy of the kentongan in villages around the country is created at the center, one that is bigger than any of the rest, and then all the other kentongan are counted and subjected to regulations that oblige them to derive their significance from the one at the center. The difference, however, was that nobody was killed in the process of kentonganisasi, and kentongan were not themselves associated with the type of power that the specter of crime evoked, so kentonganisasi did not attract the same attention as Petrus. With Petrus, the people who were killed were invested with a "suprabiological force" that should resist death (their tattoos, invulnerability, force of expression that knows no bounds); and yet, it seemed, the state could even control this. 87

\section{Prologue: Post-Suharto Indonesia: Ninjas and Sorcerers}

In the immediate aftermath of Suharto's fall, the Muslim (especially Nahdlatul Ulama) population of Java has been terrorized by a mysterious killing campaign directed against so-called dukun santet (sorcerers). These killings, which began in Banyuwangi and have since spread throughout Java, bear more than a passing resemblance to Petrus. As with Petrus, they seemed to begin as "local" killings (sorcerers being even more feared and hated locally than preman) but have since been imitated by highly organized squads of masked men using walky-talkies, handsignals, and maps. These squads reportedly select their victims from lists of dukun

85 Those that are sent-off for outside reform are sent to collaborating pesantrèn or to ex-convict organizations that escaped Petrus through connections to the right powers in Jakarta. These latter groups, sometimes trained by the military, are useful for political purposes like instigating riots since their members can always be threatened with being killed or imprisoned if they do not cooperate. For example, one such group was used in the violent take-over of the PDI (Indonesian Democratic Party) headquarters in July 1996.

86 Bekking means that a gang is "backed" by people in the military. Such bekking protects the gang from the law and allows the military to be involved in protection rackets without appearing to be so.

87 I borrow the phrase "suprabiological force" from a paper by James T. Siegel. See Siegel, "A New Criminal Type in Jakarta: Counter Revolution Today." Paper presented at the conference, Crime and Punishment: Criminality in Southeast Asia, sponsored by the Center for Asian Studies. Amsterdam, March 20-22, 1997. 
santet prepared by local government officials. ${ }^{88}$ The killers themselves are known as ninja (a term that first gained currency in East Timor where it meant groups of unidentified, masked-men who burst into houses to kidnap, threaten, or murder locals $)^{89}$ and are widely believed to be members of the military, or at least militarytrained.90 As with the Petrus killings, the victims of these new mysterious killings are brutally murdered, their corpses mutilated and left on display in public places (the corpses are stabbed dozens of times, often chopped up, and then hung in sacks near mosques). As I write this, almost two hundred such killings have been recorded.91

Despite the similarities between the Petrus and dukun santet killings, however, the differences between the two cases are also instructive. Besides the obvious fact that the population being terrorized consists mainly of religious preachers (guru ngaji) rather than ex-convicts, tattoo-wearers, and gangs, what stands out about the Banyuwangi campaign is the widespread failure of the killings to attract people's support. On the contrary, as soon as the killings became an issue in the press, the public response was to identify with the victims and to fear the ninjas (whom National Police Chief, Lieutenant General Roesmanhadi, then tried to claim were PKI, a claim that was greeted in most quarters by derision). ${ }^{92}$ This fear-combined with suspicions that elements in the military are masterminding the affair-has translated into an extremely militant use of the ronda and other local security systems: ${ }^{93}$ frequencies and densities of patrols have been stepped-up, cars (especially those with Jakarta plates) are stopped by local guards as they enter villages and their occupants asked to produce identity papers, strangers lurking around pesantrén or asking questions about people's whereabouts are apprehended and questioned. ${ }^{94}$ Ironically, in many areas this strengthening of the ronda has had the effect of weakening rather than strengthening Siskamling; for rather than acting on behalf of the Police, local guards actually main hakim sendiri, sometimes even mobilizing enough people to reclaim for "mass punishment" ninjas that had already been turned over to the Police. ${ }^{95}$ In other words, a gap has opened up between the logic of local security practices and the logic of centralized policing. As Central Java's Police Chief, Major General Nurfaizi, complained after ronda guards killed a suspected ninja:

\footnotetext{
88 On how the killings in Banyuwangi were organized and how they differ from local killings of dukun santet, see Tempo, October 20-26, 1998, pp. 18-21.

89 Benedict Anderson, personal communication.

90 On the claim that the ninjas include deserters from Kopassus and their trainees, see Detak 17 (November 3, 1998).

91 Jakarta Post, November 6, 1998.

92 Jakarta Post, November 5, 1998.

93 In addition to strengthening its guard watches, at least one pesantrèn reportedly mobilized one thousand ghosts to defend against the threat of ninja. Pikiran Rakyat, October 29, 1998, p. 4.

94 For example, see Pikiran Rakyat, November 1, 1998, pp. 1, 6; Pikiran Rakyat, November 8, 1998, pp. 1, 8; Pikiran Rakyat, November 12, 1998, p. 4.

95 In Central Java alone, at least thirty-nine people suspected of being ninjas have been killed in mob violence. The victims are often hung, decapitated, chopped-up, and then burned. Many have later been found to people with histories of mental illnesses or passers-by. See Jakarta Post, November 11, 1998. In Kuningan, West Java, more than seven hundred people attacked a police station where it was thought four ninjas were being held. Pikiran Rakyat, November 1, 1998, p. 8.
} 
Their security system was exaggerated and uncontrollable. They do not even have a proper plan. People should also have to obey the existing laws without conducting such mob rule. ${ }^{96}$

The logic of these killings, which targets strangers and unidentifiable people rather than people whose names are on lists, is outside of state control. It is this lack of control that the police chief finds disturbing. And with good reason: on at least one occasion the so-called ninjas killed by local people were in fact uniformed police officers (a case that resulted in revenge killings by the Police). .97

In sum, if we return to the comparison to Petrus, the main difference is that the Banyuwangi case shows no clear signs of having established a symbolic recuperation. Rather, what one finds is all sorts of competing claims as to what the real source of fear is: Is it dukun santet that one should be afraid of? Or the PKI? Or ninja? Or the Police? Or perhaps the ronda guards with their road blocks and their fear of strangers? Depending on the answer, one should seek security in either the authority of the ninja, the Army, the ronda, ghosts, or perhaps even a particular political party. All these possibilities, most of which were already latent in Petrus, are now out in the open for everyone to see. In the end, if a symbolic recuperation is possible for the dukun santet killings, it will undoubtedly take the least surprising and most reassuring of the possible answers to those questions: that the ultimate source of this new killing campaign-and thus the source of fear-is Suharto himself. ${ }^{98}$ Given the brutality of the violence on all sides, however, one wonders if such a recuperation is even possible.

96 Jakarta Post, November 11, 1998.

97 Pikiran Rakyat, November 2, 1998, pp. 1, 11; Jakarta Post, November 6, 1998, p. 1.

98 On Amien Rais's claim that Suharto is behind the killings, see Jakarta Post, November 6, 1998, p. 1. 